\title{
GIRL MEETS BOY: POSTCYBORG ETHICS, INDIVIDUAL IDENTITY AND COLLECTIVE RIGHTS IN THE POSTHUMAN AGE
}

\author{
Mónica Calvo Pascual \\ Universidad de Zaragoza \\ mocalvo@unizar.es
}

\begin{abstract}
Taking as a point of departure the novel's setting in a world controlled by online networks and global corporations, together with human beings' position as decoders of the excess of information in contemporary culture, this essay provides a posthuman interpretation of Ali Smith's Girl meets boy (2007) under the lenses of Rosi Braidotti's postulates on posthumanity and Heidi Campbell's postcyborg ethics. Thus, I analyse the ways in which the novel probes into the limits of humanity and individual identity as related to virtual environments, body politics and sexuality. Attention is also paid to the novel's raising of collective awareness and social struggle against injustice and the oppression of women, homosexuals and third-world citizens as a response to their invisible, naturalized dehumanization by the contemporary global politics of consumer culture.
\end{abstract}

Keywords: Posthuman, postcyborg ethics, identity, sexuality, consumer culture, globalization. 


\title{
GIRL MEETS BOY: LA ÉTICA POST-CÍBORG, LA IDENTIDAD INDIVIDUAL Y LOS DERECHOS COLECTIVOS EN LA ERA POSTHUMANA
}

\begin{abstract}
RESUMEN. Partiendo de la contextualización de la novela en un mundo controlado por redes virtuales y corporaciones globales, junto con la posición de los seres humanos como descodificadores del exceso de información presente en la cultura contemporánea, el presente artículo ofrece una interpretación posthumana de la novela de Ali Smith Girl meets boy (2007) bajo el prisma de los postulados de Rosi Braidotti acerca de la posthumanidad y de la ética postcíborg elaborada por Heidi Campbell. En este sentido, analizaré cómo la novela explora los limites de la bumanidad y de la identidad individual en su relación con los entornos virtuales, las politicas del cuerpo y la sexualidad. Asimismo, estudiaré cómo la novela llama a la conciencia colectiva y la lucha social contra la injusticia y la opresión de mujeres, homosexuales y ciudadanos del tercer mundo como respuesta a la deshumanización invisible y naturalizada a la que están expuestos en el mundo capitalista, consumista y globalizado.
\end{abstract}

Palabras clave: Posthumano, ética post-cíborg, identidad, sexualidad, cultura del consumo, globalización.

Received 10 December 2017

Revised version accepted 29 May 2018

\section{INTRODUCTION}

Ali Smith's Girl meets boy (2007) ${ }^{1}$ is one of the contemporary rewritings of classical myths commissioned by Scottish publisher Canongate, aimed at providing old myths and legends with relevance in present day culture. As such, the novel has received critical attention as a queer retelling of Ovid's myth of Iphis and Ianthe (Ranger 2012; Mitchell 2013) and as a self-conscious reflection on the power of myths - ancient and contemporary alike - to construct reality (Doloughan 2010). Yet, this focus on the potential of myth-making and the creative reversal of Ovid's metamorphosis has led to the neglect of nearly one half of the novel, which will occupy a central place in this article. Structured in five sections, alternately narrated by two Highland sisters in their twenties, Anthea and Imogen, Girl meets boy provides a dialogic perspective on a series of interrelated events. Namely, Anthea falls in love with a young anti-capitalist woman who sprays graffiti protest messages denouncing women's worldwide oppression and global capitalist exploitation, while Imogen (a.k.a. Midge) has to face the double challenge of

1 Following Ali Smith, I will only capitalize "Girl" in the title of the novel. 
GIRL MEETS BOY: POSTCYBORG ETHICS, INDIVIDUAL IDENTITY AND COLLECTIVE RIGHTS...

coming to terms with her sister's lesbianism and finding her own place within (or without) the sexist heteropatriarchal context of the water-bottling company where she works as creative personnel. The "dialogue" established through the combination of voices offers a two-fold exploration of individual identity (a human, sexed and gendered one) and its construction and deconstruction in the context of a contemporary late-capitalist globalized consumer culture overpowered by an excess of media-promoted and virtual data, blind to the needs and rights of others whose difference has made their "humanness" invisible to the oblivious majority of western citizens.

\title{
2. POSTHUMANISM, THE POSTHUMAN AND POSTCYBORG ETHICS
}

That not all human beings are attributed the same degree of humanity is a historical fact that seems to stem from the Classical and Neo-classical - i.e, Humanist - model of humanity. As Rosi Braidotti puts it in her study The Posthuman (2013),

\begin{abstract}
At the start of it all there is He: the classical ideal of "Man", formulated first by Protagoras as "the measure of all things", later renewed in the Italian Renaissance as a universal model and represented in Leonardo da Vinci's Vitruvian Man [...]. An ideal of bodily perfection which, in keeping with the classical dictum mens sana in corpore sano, doubles up as a set of mental, discursive and spiritual values. Together they uphold a specific view of what is "human" about humanity. Moreover, they assert with unshakable certainty the almost boundless capacity of humans to pursue their individual and collective perfectibility. (13)
\end{abstract}

Luce Irigaray (1985a, 1985b), among others, points out that the Classical and Humanist ideal of Man is, needless to say, male, Caucasian, able-bodied, and presumably heterosexual. Hence, as Braidotti argues, "the sexualized, racialized, and naturalized others [...] are reduced to the less than human status of disposable bodies" (2013: 15). The Italian-Australian philosopher acknowledges the theoretical impact of what she calls feminist anti-Humanism, or postmodern feminism, through its rejection of the Humanist ideal of "Man" and the emphasis laid on diversity, difference and internal fracture within categories like women, the native or "the naturalized other (animals, the environment or earth)" (27). Thus, starting from the legacy of feminist and poststructuralist anti-Humanism, Braidotti proposes "an affirmative posthuman position" (38) that transcends the centrality of "Man" through the celebration of difference. For her, the reconsideration of the category "human" is an urgent issue triggered, among other factors, by the rapid changes taking place in the world in the last few decades in terms of environmental crises, an increasingly globalized economics, technological development, and "the global infotainment apparatus of the new multimedia environment" (7). 
In line with this, Heidi Campbell discusses how the discourse of cyborgs and the posthuman "takes seriously issues related to the role and status of the human in a world of rapidly increasing technological developments" (2006: 280). Due to these technological developments, especially the expansion of Virtual Reality and the Internet throughout the capitalist countries in the 1990s, the notion of the cyborg - so far associated exclusively to the realm of science fiction - was brought into the public sphere. A cyborg came to be understood not merely as a physical combination of human being and machine but as the human being whose life and work are intertwined with a virtual dimension through the use of the Internet and Virtual Reality. This is what N. Katherine Hayles (1995) calls "metaphoric cyborgs": people whose entertainment activities or jobs rely on their use of technology, e.g., teens in videogame arcades, computer keyboarders or neurosurgeons aided by fiber-optic microscopy in operations (322).

Following engineer and performance artist Steve Mann's counter-surveillance critiques, ${ }^{2}$ Campbell describes the cyborg era as "the assimilation and acceptance of technology into our intimate spaces" (2006: 286; original emphasis) as "illustrated in the assimilation of the Internet into the patterns of our everyday life" (286) or the proliferation of surveillance technology in public places, "enabling the collection and storage of private data by a variety of political economic organizations" (286). The unquestioned assimilation of invasive technologies in our private lives leads, for Mann (2003a), to a postcyborg age in which people become reducible to their data, and society and humanity are seen as mere information. As a necessary response to this lack of interrogation, Campbell calls for a "postcyborg ethics" that raises awareness of the ways in which "our world has been manipulated by technology, the rhetoric surrounding it, and the unseen myths advocated by technology use, such as promoting freedom, malleability, and autonomy. [...] [O]ur world is infused with technological constraints and possibilities we have allowed to take root" (2006: 287). Thus, this ethics advocates a "radical questioning of the social, political, and economic structures that have emerged in the information age" (287), including a concern with how human relationships and our sense of personhood are defined and determined by contemporary techno-culture. In other words, postcyborg ethics "attempts to reflect on how we are shaped by the technology we have accepted and assimilated into our life sphere and the effects on our personhood and privacy. [... It] addresses our need to respond critically to the new technological us, and provides insight into how we already resemble and interact with our technologies" (288, 290; original emphasis). In Braidotti's terms, "we need to devise new social,

\footnotetext{
2 For a more detailed account of Mann's activist interventions see Mann 2003a, Mann 2003b and Mann et al. 2003.
} 
GIRL MEETS BOY: POSTCYBORG ETHICS, INDIVIDUAL IDENTITY AND COLLECTIVE RIGHTS...

ethical and discursive schemes of subject formation to match the profound transformations we are undergoing" (2013: 12) since the latest turn of the century.

On the other hand, as a result of the developments in computation and virtual spaces, the discourse of cybernetics since the 1980s tended to construct "the human as a set of information processes, privileging mind over body and erasing the embodied experience of the corporeal subject" (Toffoletti 2007: 16). This interpretation of the human, which is but a sequel of the centuries-long philosophical tradition of disparaging the body as inferior to the intellect and of connecting it to nature and the female, has been criticized by feminist theorists like Braidotti (2013) and Kim Toffoletti (2007). Such construction of cybernetics, "at odds with a feminist politic that seeks to redress the negation of female subjectivity and experience" (Toffoletti 2007: 16), leads to the main tenet in Hayles's landmark study How We Became Posthuman (1999): the reconceptualization of the posthuman as embodied information embedded in the frame of a nature-culture continuum already pointed out by the word cyborg itself, coined in 1960 by Manfred E. Clynes and Nathan S. Kline, as a productive combination of cybernetics and organism.

The analysis that follows thus embraces both Braidotti's and Hayles's affirmative definitions of the posthuman as embodied information that transcends the centrality of "Man" and Campbell's postcyborg ethical interrogation of technologicallymediated globalized contemporary consumer culture.

\section{GIRL MEETS BOY: INFORMATION AND INDIVIDUAL IDENTITY}

From its very outset, Girl meets boy is conspicuously characterized by excess in its use of citation and allusion: from the unsigned quoted in Classical Greek in the dedication of the book (Sapho's fragment 116, as quoted by Athenaeus of Naucratis in the 13th book of his Deipnosophistae) and the five apparently disparate quotations that precede the first chapter, by E.M. Forster, Joseph Roth, Kathy Acker, Judith Butler and John Lyly, to the Gunn sisters' constant references to contemporary popular culture, classical gods and myths, historical events and personages, current affairs and even London and Inverness topography. References to popular culture abound, with television, cinema and music as their main sources, including TV programmes "Blind Date"3 and "The Generation Game" (Smith 2007: 4), TV announcer Cilla Black (4), "Johnny Depp in Pirates of the Caribbean" (43), the Spice Girls and "the video of Spiceworld with Sporty Spice on the limited edition tin" (51), George Michael, Big Brother, the Eurovision

\footnotetext{
3 I reproduce the titles of cultural products faithfully as they appear in the novel, as the text makes no distinctive use of italics or inverted commas to highlight the status of cultural products as films, songs, programmes, etc., thereby increasing the difficulty of decoding by the reader.
} 
Song Contest, Buffy the Vampire Slayer and its characters Willow and Tara (51), Tracy Chapman $(53,55)$, "Judi Dench in that film Notes on a Scandal" (56), "that gay woman doctor character in ER whose lovers always die in fires and so on" (58), TV programme University Challenge (63), former Director-General of the BBC Greg Dyke (68), Channel Four (70), Top of the Pops (72), "Daniel Craig in Casino Royal" and Ursula Andress (83), Mozart (101), the seven dwarves (141), Mendelssohn (149), The Pussycat Dolls' song "Don't Cha (Wish Your Girlfriend Was Hot Like Me)" (152), TV programmes Antiques Roadshow, Songs of Praise, Question Time and Newsright Review (153), the Canadian Barn Dance and the Gay Gordons (159). The relevance of many of these allusions clearly stems from their status as signifiers of gay and lesbian culture; yet, the presence of many others seems to have a different purpose, to which adds the frequency of allusion to gods, myths and legends as varied as Ovid's ever-present myth of Iphis and Ianthe, Isis being compared to "the Virgin Mary at Lourdes" (92), Daedalus (95), "the Hanging Gardens of Babylon" (105), Venus, Artemis, Dionysos, Cupid and the Loch Ness Monster (153-154), or Minoan cannibals (156).

Besides, in the mood of the historiographic metafiction so fashionable in the past few decades, a focus on current political affairs - like "the man who owns Stagecoach buses [who] had that million-pound poster campaign all over Scotland where they had pictures of people saying things like 'I'm not a bigot but I don't want my children taught to be gay at school"' (60) or the implementation of homophobic educational policies in countries like Poland, Russia, Italy and Spain (61) - mixes with references to historical events and personages, most of them connected with past struggles against gender, national and political oppression. The past is thus deployed to mirror and comment on the present by establishing parallels between past injustices and contemporary oppression of women and sexual minorities: the Mud March (7), Burning Lily [Lilian Lenton] (9), the procedures of the Cat and Mouse Act to counter the suffragettes' struggle, the ban on Gaelic language "after the 1745 rebellion and the 1746 defeat" of Bonnie Prince Charlie's army at the Battle of Culloden (54), John Knox (154) and the reproduction of a fake "telegram poem" with which he excuses himself for missing the protagonists' imaginary wedding (155). The air of reality and local colour in the novel is aided by the incorporation of detail in terms of urban topography as we follow the protagonists' footsteps in Inverness - the Eastgate Centre (132), the Town House (134), the Castle (135), the cathedral and Eden Court Theatre (136), the statue of Flora MacDonald (137), the Ness Bank $(137,150)$ - and London alike: Leicester Square (110), the statues of William Shakespeare and Charles Chaplin, Trafalgar Square, Nelson's Column and Big Ben (112), or the memorial of the (faceless) women who fought in World War II, whose representation by empty clothes (114-116) 
serves as the grounds for the critique upon patriarchal disregard for women's value beyond their outfits and the historical lack of recognition of individual heroines.

The inclusion of such a vast array of historical, geographical and cultural allusions in a really brief novel (161 pages including the empty pages between chapter divisions) has an overwhelming effect on the reader that wishes to decode all the information. In other words, what is apparently a rather simple easy read turns out to be a maze of information that places the reader in the position of a data processor, following N. Katherine Hayles's posthuman approach to human beings, defined by cybernetics as "a set of informational processes" (1999: 4). Indeed, the role of the reader as a posthuman decoder fittingly accompanies the posthuman view of global politics and individual identity portrayed in the novel. The questioning of the status of human identity in the contemporary technomediated world that, following Campbell, we may define as postcyborg ethics, is made explicit when Anthea reflects on the instability and contingency of her sense of self in the following terms:

I was tired of having to be anything at all. I felt like the Internet, full of every kind of information but none of it mattering more than any of it, and all of its little links like thin white roots on a broken plant dug out of the soil, lying drying on its side. And whenever I'd try to click on me, try to go any deeper when it came to the meaning of "I", I mean deeper than a single fast-loading page on Facebook or MySpace, it was as if I knew that one morning I'd wake up and try to log on to find that not even that version of "I" existed any more, because the servers all over the world were all down. And that's how rootless. And that's how fragile. And what would poor Anthea do then, poor thing? (Smith 2007: 23-24)

The extract clearly stands as a twofold critique on the overwhelming presence of the Internet in the lives of contemporary westerners. It suggests what the New York Technorealist School of cyber thought exposed in the fourth principle of their 1998 Technorealism Manifesto (www.technorealism.org): that information is not the same as knowledge. The excess of information in the Internet has resulted in a gradual devaluation of knowledge and professional expertise, as it is believed that "everything is in there" and, consequently, everybody has access to (right or wrong) information on every field, from literary criticism to the medical profession. The metaphor of the rootless, dying plant therefore illustrates both the death of deep, scientifically-grounded knowledge and the consequent intellectual superficiality of our society, together with the shallowness and artificiality of individual identity resulting from many people's obsession with creating attractive social network profiles rather than cultivating their inner lives. ${ }^{4}$

\footnotetext{
4 Studies have been made on how the pop-up and copy-and-paste character of the Internet affect the human mind, some of the most popular being IT expert Nicholas G. Carr's The Shallows: What
} 


\section{CORPORATIONS AND GENDER IN CONSUMER CULTURE}

The overarching presence of the virtual in everyday life is paralleled in the novel by the ever-expanding power and control exerted by the - ironically named - Pure company, as its sexist managing director, Keith, intends to transform the original water-bottling enterprise into a multi-faceted firm that infiltrates in each and every aspect of human routines without the consumers' awareness of its absolute monopoly:

What I want, he says, is to make it not just possible but natural for someone, from the point of rising in the morning to the point of going to sleep again at night, to spend his whole day, obliviously, in Pure hands.

So, when his wife turns on his tap to fill his coffee machine, the water that comes out of it is administered, tested and cleaned by Pure. [...] When he picks up the paper to read at the breakfast table, [...] it's one of the papers that belong to Pure. When he switches on his computer, the server he uses is Pure-owned, and the breakfast tv programme he's not really watching is going out on one of the channels the majority of whose shares is held by Pure. [...] And should our man feel like watching some high-grade porn [...] he can do so courtesy of one of the several leisure outlets owned, distributed and operated by Pure. [...] Pure Product is everywhere. Pure is massive throughout the global economy. (Smith 2007: 117-119)

Beyond the obvious expansionist economic drive behind Keith's project, one can picture in his description a kind of dystopian environment of absolute control on opinion and ideology through ownership of different media by the same company, which resonates with distant echoes from George Orwell's Nineteen Eighty-Four "thought police" (1949). Besides, the emphasis on marketing techniques and brands leads us to scrutinize the representation of the process of identity construction in the book, as embodied by the heterosexual Gunn sister, Imogen. In her sociological study Consumer Culture (1996) Celia Lury links consumer society to the flourishing of individualism, understanding consumer culture as a source of the contemporary belief that identity is an asset, a possession, and a cultural resource. In her view, consumer culture contributes to a relationship to one's own identity that is more and more self-reflexive; much like the creation of social network trendy profiles, identity thus consists in a process of self-fashioning that is carried out by means of the development of tastes, lifestyles, and elements related to health, fashion and beauty, always after the dictates of popular culture and the mass media as the loudspeakers of hegemonic ideology.

the Internet is Doing to Our Brains (2011) and The Glass Cage: How Our Computers Are Changing Us (2015). On the influence of social networks in the affective and social spheres, see MIT Professor Sherry Turkle's Alone Together: Why We Expect More from Technology and Less from Each Other (2017). 
GIRL MEETS BOY: POSTCYBORG ETHICS, INDIVIDUAL IDENTITY AND COLLECTIVE RIGHTS...

In this context of consumer culture, women's bodies have undergone a process of commodification (they have become objects to be sold, purchased and advertised), while the aesthetics of slenderness has come to be associated in the era of consumption to a higher standard of living and, consequently, to social class - not only because healthy food (fruit, fresh vegetables, not to mention the growing trend of eating organic products) is more expensive than processed food with its high caloric content, but also because engaging in the fitness industry involves the need of free time. A logical outcome of this tendency is the wish, on the part of the lower classes, to identify with the richer by means of physical appearances and fashioning a body that does not betray their "unhealthy" habits and lack of exercise.

The association of slenderness and beauty as social markers of success links with the feminist critiques of the gender backlash that started in the late 1980s in Anglo-American societies and which we still suffer from today. Naomi Wolf's The Beauty Myth: How Images of Beauty are Used against Women (1990) is an unquestionable touchstone that redefined the relation between female identity and the beauty ideal. As she denounces, all the achievements of the women's liberation movement were countered by a new weapon she named the beauty myth: a fixation with physical "perfection" that traps contemporary women psychologically in a never-ending spiral of self-consciousness and self-hatred, in their fight to adjust to the impossible definition of beauty that society imposes through the mass media and the advertising industry. Wolf also explores the socioeconomic factors that have led to the media- and culture-imposed canon of feminine beauty, and which reinforce the fact that female identity in patriarchal society cannot be separated from women's appearances. The external imposition of a beauty canon produces damaging effects upon our sense of identity as we learn to see ourselves not through our eyes but through those of patriarchal standards. For Wolf, this myth is the worst attack against women because it causes physical destruction and psychological exhaustion, at the same time that it is an economically-motivated manipulation:

The modern arsenal of the myth is a dissemination of millions of images of the current ideal; although this barrage is generally seen as a collective sexual fantasy, there is in fact little that is sexual about it. It is summoned out of political fears on the part of male-dominated institutions threatened by women's freedom, and it exploits female guilt and apprehension about our own liberation - latent fears that we might be going too far. [...] And the unconscious hallucination grows ever more influential and pervasive because of what is now conscious market manipulation: powerful industries - the $\$ 33$-billion-a-year diet industry, the $\$ 20$-billion cosmetics industry, the \$300-million cosmetic surgery industry, and the \$7-billion pornography industry - have arisen from the capital made out of unconscious anxieties, and are 
in turn able, through their influence on mass culture, to use, stimulate, and reinforce the hallucination in a rising economic spiral. [...] The myth is undermining - slowly, imperceptibly, without our being aware of the real forces of erosion - the ground women have gained through long, hard, honorable struggle. (1991: 16, 17, 19)

Similarly, in her book Backlash: the Undeclared War against American Women (1991) Susan Faludi shows how consumer culture distorts feminist concepts in order to sell its products; she denounces how feminism is now being defeated by consumerism:

We live in a time when the very fundaments of feminism have been recast in commercial terms [...] The feminist ethic of economic independence has become the golden apple of buying power - a "power" that for most women yields little more than credit-card debt, an overstocked closet, a hunger that never gets sated because it's a hunger for something beyond the material. The feminist ethic of self-determination has turned into the golden apple of "self-improvement" - an improvement dedicated mostly to one's physical appearance, self-esteem, and the fool's errand of reclaiming one's youth. And the feminist ethic of public agency has shape-shifted into the golden apple of publicity - the pursuit of a popularity that hinges not on how one changes the world, but on how marvellously one fits into its harness. (2006: xiv-xv)

Faludi's description above seems to be the pattern according to which the character Imogen is created: after learning that her younger sister is a lesbian, she feels the need to assert how well she fits into the harness of mainstream society by stressing her desired "normalcy" together with her professional and personal success in a highly individualistic and materialistic sense:

I am putting on my Stella McCartney Adidas tracksuit bottoms. I am lacing up my Nike runners. I am zipping up my Stella McCartney Adidas tracksuit top. I am going out the front door like I am a (normal) person just going out of a (normal) front door on a (normal) early summer day in the month of May and I am going for a run which is the kind of (normal) thing (normal) people do all the time. [...] I am down to just over seven stone. I am doing well. [...] I got a raise. I get paid thirtyfive thousand before tax. I can't believe I'm earning that much money. Me! I am clearly doing the right thing. (Smith 2007: 51-52)

The money she earns and the commodities she can afford measure who she is and how well she is doing, according to her preconceived standards. In line with Braidotti's argumentation, "subjectivity is rather a process of autopoiesis or self-styling, which involves complex and continuous negotiations with dominant norms and values and hence multiple forms of accountability" (2013: 35). Moreover, in her efforts to fit, Imogen holds herself accountable to her homophobic sexist male workmates, very tellingly called Dominic and Norman as 
GIRL MEETS BOY: POSTCYBORG ETHICS, INDIVIDUAL IDENTITY AND COLLECTIVE RIGHTS...

they embody "dominant norms" (Doloughan 2010: 246) and values in the novel: she forces herself to laugh at the lesbiphobic jokes they make despite her new awareness of her sister's sexuality, and the disgust at her own behaviour makes her vomit after their conversation. Her self-containment and lack of expression are connected as well with her manifest bulimia. Imogen's self-induced vomiting and obsession with her weight are the other way in which Imogen tries to shape her identity: through her Humanist sense of individual (bodily) "perfectibility", to borrow Braidotti's term again.

Imogen's individualism 5 and lack of empathy with collective problems are betrayed by the way she blames her mother's feminism for her parents' divorce and her sister's lesbianism:

I will never leave my children when I have fallen in love and am married and have had them. I will have them young, not when I am old, like the selfish generation. I would rather give up any career than not have them. I would rather give myself up. I would rather give up everything including any stupid political principle than leave children that belonged to me. Look how it ends. Thank God the feministy time of selfishness is over and we now have everything we will ever need, including a much more responsible set of values. (Smith 2007: 53-54)

The ironic textual implications here obviously echo Faludi's denunciation of the violent reaction of the dominant ideology in the Anglo-American world in the 1980s and 1990s against the social progress effected by the women's liberation movement in the previous decade. The most obvious manipulation is the recurrent false messages that feminism is no longer meaningful because equality has been achieved and that it has only brought about a less comfortable position for women who, through their focus on the professional sphere, either lose their feminine role as family nurturers or have the double burden of working outside and inside the home. Even worse, the neoconservative groups that promoted the antifeminist reaction disguised it as a defence of women's well-being and disseminated it through media images showing that feminism had failed and at the same time it was no longer necessary; that women were happier before the women's movement when they devoted all their time and energy to doing the household chores and bringing up their children. It is most ironic that the words "we now have everything we will ever need" are voiced by the female character that lives in the grips of an eating disorder, finds it normal to be the only woman in the Pure board of creative personnel, and submits herself to the denigrating attitude of male chauvinistic workmates who treat her as a clown and find it funny to look up "pictures on the net of women fucking horses and dogs" (Smith 2007: 64).

\footnotetext{
5 Imogen's individualism and lack of connection are ironically highlighted by the fact that she feels safest by talking on her mobile phone to answering machines.
} 


\section{5. "THIS MUST CHANGE": RAISING AWARENESS ON COLLECTIVE RIGHTS}

Girl meets boy is a politically committed novel regarding not only the rights and oppression of women and sexual minorities, but also of the people living in third world countries that are brutally exploited by the global economics of late capitalism; in other words, of all those groups historically excluded from the Humanist conception of the human. According to Braidotti's analysis of our current posthuman environment, "the issue of both ecological and social sustainability is at the top of most governmental programmes across the world, in view of the environmental crisis and climate change. [...] Globalization means the commercialization of planet Earth in all its forms, through a series of interrelated modes of appropriation" (2013: 6, 7). Her denunciation of "the turning of the ecosystem into a planetary apparatus of production" (7) materializes in Girl meets boy through the Pure water-bottling company with its commercial interests in China and India, which include the building of water-dams that block the Indian population's access to fresh water and ruins their crops (Smith 2007: 123). Keith offers Imogen a promotion to move to London and lead the "Pure Dominant Narrative Department" (121). His motto to manipulate information and counteract critical reports is "Deny Disparage Rephrase" (122) to the extent of suggesting that she should describe the Indian protesters as "ethnic troublemakers who are trying to involve us in a despicable religious war. Use the word terrorism if necessary. Got it?" (123).

Two combined incidents shake Imogen's worldview to the point of quitting her job and adopting an activist attitude from that moment onwards: first, Keith's demagogic use of language when he argues that water is not a human right but a human need - "the perfect commodity" (37) - and therefore it is the company's "human right" to sell it (124); and second, the fact that he sexually harasses Imogen by forcing her to see that "his trousers are repressing an erection" (123) when they are alone at the deserted Pure Base Camp in London. For the first time, Imogen gives free rein to her anger and expresses her disgust to Keith before departing to Inverness. One could also add that, at this point, she begins doing justice to the nickname by which everyone calls her and which she insistently rejects, "Midge": the tiny but fierce Highland-autochthonous gnat species that has recently become a celebrated unofficial symbol of Highland Scotland for its tenacious single-mindedness, embodying the land's historical resistance to invasion by conquering nations. The election of this nickname is by no means accidental as it metaphorically suggests Midge's final metamorphosis and newly acquired resistance to patriarchal impositions on her identity.

Significantly enough, Imogen's perspective on life, her identity, and women's rights turns upside down when she finally shatters her self-containment by rejecting 
GIRL MEETS BOY: POSTCYBORG ETHICS, INDIVIDUAL IDENTITY AND COLLECTIVE RIGHTS...

her boss's sexual advances, quitting her job and expressing her feelings to her exworkmate Paul. Yet, only after Imogen and Paul make love does she feel fully liberated:

I'm tired of feeling things I never get to express, things that I always have to hold inside, I'm fed up not knowing whether I'm saying the right thing when I do speak, anyway, I'd thought I'd be brave, I thought it was worth it, and I hope you don't mind me saying.

Words are coming out of me like someone turned me on like a tap. It's Paul. He turns me on! [...] And after that we'll all go for something to eat.

(I have thought for a long time that the way my clothes hang on me is more important than me inside them.) [...] (THIS MUST CHANGE). (131, 138, 140)

It is precisely that sentence, "This must change", that closes all the anti-capitalist and anti-patriarchal messages that Robin and Anthea graffiti on the walls of every public building and monument in Inverness - which they sign alternately as "Iphis and Ianthe the message girls 2007" and "Iphis and Ianthe the message boys 2007". Imogen's borrowing of the phrase is followed by her offer to collaborate with the two activists as a marketing specialist by making their messages more effective since they are far too long, as the following example shows:

WOMEN OCCUPY TWO PERCENT OF SENIOR MANAGEMENT POSITIONS IN BUSINESS WORLDWIDE. THREE AND A HALF PERCENT OF THE WORLD'S TOTAL NUMBER OF CABINET MINISTERS ARE WOMEN. WOMEN HAVE NO MINISTERIAL POSITIONS IN NINETY-THREE COUNTRIES OF THE WORLD. THIS MUST CHANGE. (137)

One of the virtues of Girl meets boy resides on its ability to efficiently bring forward important challenges to gender and sexual discrimination in a lighthearted, often ironic way that does not alienate the reader, therefore reaching a wider audience. Through the girls' messages and the funny debate they motivate among the Inverness population, the text denounces issues as dramatic and contemporary as the fact that millions of girls are killed in the world merely because they are not boys $(133)^{6}$ or the tremendous gap between men's and women's salaries (134). This adds, of course, to the critique of the harmful consequences of the so-called beauty canon internalized by many women and the psychological effects of backlash anti-feminist messages in their life choices, as analysed above in the figure of Imogen. ${ }^{7}$ That Smith's novel has a marked feminist

\footnotetext{
6 The estimates given about the number of baby girls killed in eastern and underdeveloped countries because they are a burden to their families sheds light on the sadly contemporariness of Ovid's myth of Iphis, which revolves around the fact that Iphis's mother raises her daughter as if she were a boy to prevent her husband from killing the new-born, as he threatened he could only afford to have a son.

7 It is also worth-mentioning that the most markedly sexist attitudes are embodied by the representatives
} 
core stands out from the very outset, as the first chapter is framed by Anthea's memories of her grandfather's accounts of how he dressed up as a girl in his youth in order to help a suffragette escape from the police and avoid prison - a narrative excuse to recall the harsh penalties and cruel measures inflicted upon the women who fought for women's franchise in the early $20^{\text {th }}$ century, like force-feeding and the infamous Cat and Mouse Act (6-17). ${ }^{8}$

Likewise, homophobic prejudice is exposed by the text's ironic questioning of stereotypes voiced by the two unsympathetic Pure workers Dominic and Norm, who refer to lesbians as "thespian", "lickian", "freakshow", "fucking dyke", "adolescent backwardness", "marked underdevelopment" (68-69), and discuss in a disdainful tone how "there's nothing to do the job. Nothing to do the jiggery-pokery with. [...] But it is good, Norman says, if you're watching and they're both fuckable" (70).? Indeed, their ignorance and lack of imagination - their belief that sexual intercourse is impossible without a penis - ludicrously echoes the trope of sexual impossibility on which Ovid's metamorphosis myth was based: the central issue in the myth of Iphis and Ianthe, rewritten by Smith's novel, was the fact that for the two girls to get married Iphis had to be, and was, transformed into a boy by goddess Isis, thereby providing the happy ending to their love story. In Robin's words, the author of the Metamorphoses “can't help being the Roman he is, he can't help fixating on what it is that girls don't have under their togas, and it's him who can't imagine what girls would ever do without one" (Smith 2007: 97). It says a lot of contemporary society that, twenty-one centuries after Ovid's time, some part of the population may still show the same phallocentric anxieties about female same-sex.

Other types of concern for Anthea's lesbianism are expressed by her older sister in a nicer, comical way - the brackets in the text marking the intrusive thoughts that interrupt her conscious train of thought:

(Oh my God my sister is a GAY.)

(I am not upset. I am not upset. I am not upset. I am not upset.) [...]

(I can't bring myself to say the word.)

(Dear God. It is worse than the word cancer.)

\footnotetext{
of the global capitalist company, Keith, Dominic and Norm, who treat Imogen and every other woman as sexual objects and silly pretty things that must laugh at their male chauvinistic jokes. Keith even ventures that he offered Imogen the promotion for her "natural instinctual caring talent" but, most of all, for her "ability to look good, look right" (Smith 2007: 120, 121).

8 The connection between suffragettes' hunger strikes for their right to be treated as political prisoners at the turn of the century has further resonances in the present, as Imogen's suffering from bulimia is a result of more subtle contemporary forms of oppressing women.

9 Their homophobic attitude extends to male homosexuals too, as they call gay men "poofs" and express their belief that "it's fucking disgusting and it leads to queer paedophilia and everything, but at least it's real sex they have, eh? But women. It's, like, how can they?" (70).
} 
GIRL MEETS BOY: POSTCYBORG ETHICS, INDIVIDUAL IDENTITY AND COLLECTIVE RIGHTS...

(My little sister is going to grow up into a dissatisfied older predatory totally driedup abnormal woman like Judi Dench in that film Notes on a Scandal. [...] I didn't think my sister was going to maybe be one of them and have such a terrible life with no real love in it.) $(49,56)$

Imogen's concerns swiftly move from blaming her parents' divorce to dismissing the idea because, if that were so, she would be a lesbian too (49), to the news piece reporting that homosexual teenagers are "six times more likely to commit suicide than teens who aren't it" (62), to her childhood memories of joining other girls bullying Robin at school for her lesbian looks in order to become the bullies' friend (72). At first she contrasts her preconception that her "little sister is going to have a terrible sad life" (56) with the fact that she sees her kissing Robin, "laughing with outrageous happiness. [...] Like they were actually happy. Or like being gay is okay, or really funny" $(56,60)$. Yet, it is her reaction to Keith's shocking proposal - her Levinasian $^{10}$ looking at the other, one might say - that suddenly opens her mind and enables her to understand the nature of her sister's feelings, as she rebukes a police officer: "Robin's not her friend, I say. Robin's her other half" (136). As discussed above, it is through both empathic and bodily connection with other human beings that Imogen's egotism and self-defence barriers are finally laid down.

\section{POSTHUMAN EMBODIMENT, CONNECTION AND CHANGE}

Individual barriers are overcome by emotional connection with the other and the merging of bodies through the free expression of sexuality not only in Imogen's but also in Anthea's case. Indeed, her lovemaking with Robin is described as a moment of embodied transcendence during with the limits between the human, the animal, the earth and the inanimate are crossed and blurred. In opposition to conservative views of lesbianism as unnatural, lesbian sex is presented as intricately connected with nature, enhancing the nature-culture continuum postulated by posthuman theorists like Hayles (1999) and transcending the hierarchical differences between the species. In Campbell's words, the posthuman or cyborg "erases differences between human and animal and animal and machine, distinctions which the human being has traditionally used to distinguish itself from its others" (2006: 284). Lesbian sex is thus represented as posthuman in the following passage:

Her hand opened me. Then her hand became a wing. Then everything about me became a wing, a single wing, and she was the other wing, we were a bird. [...] Was I briny, were my whole insides a piece of sea, was I nothing but salty water with a mind of its own, was I some kind of fountain, was I the force of

\footnotetext{
${ }^{10}$ For further information on the ethical implications of encountering the face of the Other in Levinas's philosophy, see Levinas (1987).
} 
water through stone? I was hard all right, and then I was sinew, I was a snake, I changed stone to snake in three simple moves, stoke stake snake, then I was a tree whose branches were all budded knots, and what were those felty buds, were they - antlers? [...] I was a she was a he was a we were a girl and a girl and a boy and a boy, we were blades, were a knife that could cut through myth, were two knives thrown by a magician, were arrows fired by a god, we hit heart, we hit home, [...] the perfect jigsaw fit of one into the curve of another as if a hill top into sky, was that a thistle? [...] We were all that, in the space of about ten minutes. (Smith 2007: 101-104)

This process of metaphorical multi-faceted transmutation into different beings can be read in the light of Braidotti's rejection of the Humanist unitary subject and her postulation of "a more complex and relational subject framed by embodiment, sexuality, affectivity, empathy and desire as core qualities" (2013: 26). To reach this end, Braidotti considers sexuality an important force to deterritorialize gender identity and its related institutions (1994), highlighting the emphasis that Patricia MacCormack (2008) lays on "the need to return to sexuality as a polymorphous and complex, visceral force and to disengage it from both identity issues and all dualistic oppositions" (Braidotti 2013: 99).

Furthermore, Anthea and Robin's intimate symbolic (unofficial) wedding by the Ness Bank is effected by their mutual promise "to go beyond [their] selves" and the rings they do not exchange are replaced by references to natural elements like the "rings that widen on the surface of a loch above a thrown-in stone" (Smith 2007: 159, 160):

Nothing more than what happens when things come together, when hydrogen, say, meets oxygen, or a story from then meets a story from now, or stone meets water meets Girl meets boy meets bird meets hand meets wing meets bone meets light meets dark meets eye meets word meets world meets grain of sand meets thirst meets hunger meets need meets dream meets real meets same meets different meets death meets life meets end meets beginning meets all over again, the story of nature itself, ever-inventive, making one thing out of another, and one thing into another, and nothing lasts, and nothing's lost, and nothing ever perishes, and things can always change, because things will always change, and things will always be different, because things can always be different. (160)

The expanding, transforming force of their love is yet again connected to the natural world as a creative process of never-ending change that brings together disparate elements, emphasizing unity in diversity, like the movement implied in the titles of the five chapters of the novel - "I", "you", "us", "them" and "all together now" - which involve a twofold shift and a step beyond: from the individual to the (lesbian) couple and from the subject to the object positions, to the transcendence of both dimensions by fusing into a communal whole. 
GIRL MEETS BOY: POSTCYBORG ETHICS, INDIVIDUAL IDENTITY AND COLLECTIVE RIGHTS...

\section{CONCLUSION}

The productive confluence of difference and sameness is one of the pivotal issues in theories of the posthuman as the reconceptualization of what it means to be human now. The celebration of difference occupies a central position in Braidotti's argumentation, as it allows for the dismantling of the discriminatory Humanist privileging of the prototypical socially, sexually and ethnically unmarked Man. Likewise, Girl meets boy relies on the creative role of difference in its own revision of the notion of humanity in two distinct but related dimensions: that of human identity in its relation to gender and sexuality on the one hand, and that of the human rights of those traditionally excluded by the concept of Man as the measure of humanity on the other. Through its use of irony and wit, the novel carries out an effective exposure of the varied ways in which contemporary mainstream society still discriminates against its "others": from the capitalist exploitation and denial of the human rights of Third World populations, to the worldwide persistence of sexist and homophobic misconceptions, attitudes and policies.

Besides, the novel's setting in a social context highly influenced by the inhumane policies of global corporations and the dehumanizing effects of the overarching intrusion of ITs in our everyday lives calls for a critical examination of their effects on human relations and individuals' sense of identity in the light of Campbell's postcyborg ethics. Thus, the novel raises awareness on the excess of Internet-generated data in present day culture by placing the reader in the position of a decoder of the excess of information provided by the extensive use of citation and allusion in the text. The individualism promoted by both the use of the Internet and capitalist consumer culture is portrayed as weakening women's sense of identity as much as adding a feeling of alienation and disconnection from other human beings. Indeed, the need for connection in contemporary capitalist wired societies is called for in the novel through the central role allotted to the creative merging of humans and nature, by which the hierarchical division between them is transcended. However, the kind of transcendence advocated in the novel is an embodied one, echoing Hayles's posthuman understanding of the self as information necessarily embodied and embedded in the nature-culture continuum in which human existence is undeniably framed.

\section{REFERENCES}

Braidotti, R. 1994. Nomadic Subjects: Embodiment and Sexual Difference in Contemporary Feminist Theory. New York: Columbia University Press.

Braidotti, R. 2013. The Posthuman. Cambridge: Politi. 
Campbell, H. 2006. "Postcyborg Ethics: A New Way to Speak of Technology". EME: Explorations in Media Ecology 5 (4): 279-296.

Carr, N. G. 2011. The Shallows: What the Internet is Doing to Our Brains. New York and London: Norton.

Carr, N. G. 2015. The Glass Cage: How Our Computers Are Changing Us. New York and London: Norton.

Clynes, M. E. and N. Kline. 1995 (1960). "Cyborgs and Space". The Cyborg Handbook. Ed. C. H. Gray. New York: Routledge. 29-35.

Doloughan, F. 2010. "Bottling the Imagination: Writing as Metamorphosis in Ali Smith's Girl meets boy". New Writing: The International Journal for the Practice and Theory of Creative Writing 7 (3): 241-251.

Faludi, S. 2006 (1991). Backlash: the Undeclared War against American Women. New York: Three Rivers Press.

Hayles, N. K. 1995. "The Life Cycle of Cyborgs: Writing the Posthuman". The Cyborg Handbook. Ed. C. H. Gray. New York: Routledge. 321-335.

Hayles, N. K. 1999. How We Became Posthuman: Virtual Bodies in Cybernetics, Literature and Informatics. Chicago, IL: University of Chicago Press.

Irigaray, L. 1985a. Speculum of the Other Woman. Ithaca, NY: Cornell University Press. Trans. Gillian C. Gill.

Irigaray, L. 1985b. This Sex Which Is Not One. Ithaca, NY: Cornell University Press. Trans. Catherine Porter, Carolyn Burke.

Levinas, E. 1987 (1947). Time and the Other. Pittsburgh, PA: Duquesne University Press. Trans. Richard A. Cohen.

Lury, C. 1996. Consumer Culture. Piscataway, NJ: Rutgers University Press.

MacCormack, P. 2008. Cinesexualities. London: Ashgate.

Mann, S. 2003a. "The Postcyborg Path to Deconism." CTheory. <http://ctheory.net/ ctheory_wp/the-post-cyborg-path-to-deconism>. (Accessed 12 November 2017)

Mann, S. 2003b. "Existential Technology: Wearable Computing Is Not the Real Issue!" Leonardo 36 (1): 19-25.

Mann, S., Nolan, J. and B. Wellman. 2003. "Sousveillance: Inventing and Using Wearable Computing Devices for Data Collection in Surveillance Environments". Surveillance \& Society 1 (3): 331-355.

Mitchell, K. 2013. "Queer Metamorphoses: Girl meets boy and the Futures of Queer Fiction". Ali Smith: Contemporary Critical Perspectives. Eds. M. Germana and E. Horton. London and New York: Bloomsbury Academic. 61-74.

Orwell, G. 1949. Nineteen Eighty-Four. London: Secker and Warburg. 
Ranger, H. A. 2012. An Intertextual Analysis of the Novel Girl meets boy and the Use of Feminist and Queer Theory by Ali Smith in her Reception of the Tale of Iphis from Ovid's Metamorphoses. Unpublished M. Phil. Thesis. University of Birmingham: United Kingdom.

Smith, A. 2007. Girl meets boy. Edinburgh: Cannongate.

Technorealism Overview. 1998. The Technorealist Manifesto. <http://www. technorealism.org>. (Accessed 28 November 2017)

Toffoletti, K. 2007. Cyborgs and Baby Dolls: Feminism, Popular Culture and the Posthuman Body. London and New York: I. B. Tauris.

Turkle, S. 2017. Alone Together: Why We Expect More from Technology and Less from Each Other. New York: Basic Books.

Wolf, N. 1991 (1990). The Beauty Myth: How Images of Beauty are Used against Women. London: Vintage. 